Tér és Társadalom 18. évf. 2004/3. 1-23. p.

Tér és Társadalom

XVIII. évf. 2004 - 3: 1-23

\title{
A REGIONALIZMUS HAJTÓERŐI MAGYARORSZÁGON
}

\section{(The Driving Forces of Regionalism in Hungary) \\ FARAGÓ LÁSZLÓ}

Kulcsszavak:

régió regionalizmus „új regionalizmus" magyar regionalizáció térelmélet

Napjaink aktuális kérdése a magyar regionalizáció továbbvitele. E tanulmány a regionalizáció ideológiai és térelméleti alapjainak tárgyalásával, az európai üj regionalizmus és a magyar gyakorlat értéketésével kíván hozzájárulni a döntés minél jobb megalapozásához. Megállapítja, hogy a jelenleg uralkodó nézet materialista, marxista és neoliberális gyökerü. E téren az.1990-es rendszerváltás sem járt paradigmaváltással. E nézettel szemben azt allítja, hogy a régiók kialakításánál választhatunk, de többnyire nincs materiális vagy a reálfolyamatokban megragadható tényszerï imperatív alapja. Ezért a regionalizáció alternatív elméleti megalapozását és gyakorlati megközelítését tartja indokoltnak. A magyar viszonyok tárgyalása során azt állitja, hogy a magyar regionalizaciónak Trianon óta nincsenek nemzetiségi kulturális alapjai. A jelenlegi gazdasági folyamatok terilleti vetületeivel sem indokolható a nemzeti szint alatti régiók kialakitása. Magyarországon a regionalizáció döntöen a tudományos és a politikai diskurzusban zajlik. De a fö mozgatóerō nem a hatékonyabb és demokratikusabb államberendezkedés, az autonóm regionalis politika feltételrendszerének a kialakitása, hanem döntö mértékben külsö európai uniós pragmatista tényezök. A szerzö véleménye szerint az „európai új regionalizmus” kifulladni látszik, és kétséges, hogy uniós támogatás nélkül a belsö hajtóerök képesek lesznek-e továbbvinni a regionalizmus ügyét, amelyet végsó soron nem egyenlö felek közötti hatalmi harc fog eldönteni.

\section{Bevezetés}

A regionalizáció kapcsán elsődlegesen tisztázandó kérdés, hogy Magyarországon a régió $a b$ ovo létezö entitás, tehát „van”, amelyet csak meg kell ismernünk, és ennek megfelelöen leképezhető az intézményi struktúrában, vagy az emberek által (szabadon) létrehozott cél-okokhoz igazodó konstrukció, tehát bizonyos esetekben úgy tartják, hogy létre „,kell” hozni? Tehát a regionalizáció mennyiben (milyen vonatkozásban) ontológiai és episztemológiai kérdés, és milyen tekintetben (mértékben) konstitúciós folyamat? Hol és mikor igaz (érvényes) inkább az egyik vagy a másik megközelítés? Van-e per se tartalmi vonatkozása is e területi (regionális) szinteknek, vagy a kialakított regionális intézmények hardwerként adnak formai kereteket bizonyos funkciók, feladatok jobb, hatékonyabb ellátásához? Ha a régiók társadalmi képződmények, akkor kik és miért hozzák létre azokat, miért éppen az az „,gazság" jut érvényre? Képes-e egyáltalán az európai új regionalizmus a neoliberális gazdaságpolitikát szolgálni? Újabb határok meghúzása, új legitimációs tér kialakítása nem mond-e ellent a folyamatot jelenleg mozgató kozmopolita, a gazdasági racionalitáson alapuló modernizációs törekvéseknek?

Mindezen kérdések megválaszolása, a folyamat értelmezése, magyarázata alapvetően két nézetrendszerben történik. Az egyik lehetséges és ma nálunk meghatározó 
megközelítés lényegét Tóth József a Mindentudás Egyetemén tartott elöadása kapcsán úgy összegezte, hogy „,a régiót nem létrehozni kell, hanem fel kell ismerni”. A megismerés tárgya és módszere már nagyon különböző lehet. Leggyakrabban a természeti környezetre vagy a gazdasági egységek és a társadalmi szereplök kapcsolatrendszerének feltérképezésére irányul. A földrajztudósok és ökológusok jelentős része a természetjog alapján a fizikai (elsősorban természeti) környezet pozitivista megismerésére és deskriptív leírására törekszik, és ezekhez igazodó „természetes régiók" kialakítására tesznek javaslatot. A klasszikus területi tudomány(ok) képviselöi, a „regionális tudomány hívöi” a teret független változóként kezelik, kváziobjektívnek tételezik fel, és annak törvényszerüségeire hivatkozva alakítanának ki régiókat. Ma Magyarországon a legáltalánosabban elfogadott az a marxistaneoliberális megközelítés, amely a gazdasági terek létében vagy kialakításában látja a regionalizáció legfontosabb tartalmi elemét, a versenyképesség javításának területi keretét. Ahogy a klasszikus ipari fejlődés területi megjelenési formájának az urbanizációs folyamatot tartották, úgy a neoliberális, posztfordista gazdaságfejlődés területi velejáróját az „új regionalizmusban” látják.

Véleményem szerint a regionalizációnak lehet, de csak ritkán van materiális vagy „tényszerü” kulturális alapja, és nem szükségszerüen vezet közigazgatási régiók kialakításához. Az új regionalizmus magyarországi megjelenését én nem a reálfolyamatokkal magyarázom, és nem belső szerves (gazdasági, kulturális stb.) fejlödés eredményének tartom, hanem az uniós integráció hatására alakuló politikai folyamatnak, amely hasonló térstruktúra kialakítását és azonos fejlesztési célok megfogalmazását szorgalmazza a csatlakozó „,keleti blokk” országaiban. Nézetemet a materialista, marxista megközelítések (szocialista rajonírozás és az európai új regionalizmus) belsö ellentmondásának feltárásával és a térelméletben kívánom megalapozni. Megállapítom, hogy a regionalizáció hatalmi harc, a régió elsősorban irányítási-politikai eszköz, társadalmi - nálunk tudományos-politikai - produktum, a nyelv segítségével létrejött diszkurzív termék, amely a praxisban nyeri el végsö értelmét. A jelenleg Magyarországon folyó regionalizmus továbbvitelének külsỏ és belsỏ hajtóeröi kifulladóban vannak, és nem várható a térszerkezet, a közigazgatási struktúra radikális megváltoztatása.

\section{Materialista, marxista (neoliberális) regionalizmus}

A marxista vagy marxizáló elméletek a gazdaság, a termelési mód változásával magyarázzák a térstruktúra változását, új típusú regionalizáció szükségességét. Az erösebben pozitivista-materialista meggyőződésủek a reálfolyamatok konkrét leképezéséböl kívánják meghatározni az adekvát térstruktúrát, és azokhoz kívánják igazítani a felépítményt, kialakítani az intézményrendszert. Mások a természeti és gazdasági feltételek által meghatározott társadalmi-politikai folyamatok jobb müködési tereit látják a régiókban. A neoliberális gazdaságpolitikát szolgáló európai új regionalizmus is ezeken az elméleti alapokon nyugszik. 


\section{Marxista elmélet}

Marx ${ }^{l}$ és Engels közvetlenül nem foglalkozott a térbeliség problematikájával. A keleti pártállamokban sokáig csak nagyon korlátozott Marx-interpretációkra volt lehetőség, így a területiség problematikája nem válhatott központi kêrdéssé. Nyugati marxista iskolák ${ }^{2}$ is inkább más politikai és filozófiai kérdésekkel foglalkoztak, mint a „területológiával”. A második világháborút követő gazdasági fellendülés alatt egyre nyilvánvalóbbá vált, hogy ugyanaz a termelési mód térben egyenlötlen fejlődést eredményez, ami nem megkerülhetö kérdéseket vetett fel. A területiség materialista megalapozásához újabb lökést adott a posztmodern diskurzus erösödése, amely sok tekintetben a francia marxista tradíciókra épült.

Az eszmei és mozgalmi értelemben is marxista Lefebvre (1991) alapvetöen mentális és valóságos tereket különböztet meg. A mentális tér a filozófia és a matematika tárgya, a valóságos terek azok a fizikai (természet) és társadalmi terek, amelyekben mindannyian élünk. A társadalmi tér absztrakt, de mégis valóságos tér, amelyet társadalmi, politikai erók formálnak, alakítanak és társadalmi kapcsolatokat, viszonyokat fejeznek ki. A (társadalmi) tér (társadalmi) produktum, a téralkotás folyamata politikai folyamat, de az így létrehozott tér már eszköze a késöbbi termelésnek. Minden társadalmi berendezkedés (termelési mód) saját képére formálja a teret, így a társadalmi berendezkedés megváltozása alapvetö térbeli változásokat is eredményez. ${ }^{3}$ Ezt fordítva is igaznak tartja: „Az élet megváltoztatásához... elöször meg kell változtassuk a teret" (Lefebvre 1991, 190). A marxizmushoz hüen a társadalmi tér alakításában döntő szerepet tulajdonít a termelési módnak, amely meghatározó a munkaerő és a termelési viszonyok újratermelésében, és egyre kisebb a jelentösége a fizikai (természet) térnek. A világpiacon történő bármi beavatkozás megváltoztatja a teret is. De a modern gazdaság nem közvetlenül alakítja az új térstruktúrát, hanem a politikán keresztül.

A nyugati marxizmus nagy túlélője, Lefebvre fel kellett hogy tegye önmagának azt a kérdést is, hogy a téralakító társadalmi viszonyokat miként alapozza meg a materiális világ. Nézetrendszerében az „elsődleges alap” a fizikai vagy természeti környezet, de nem ez az ok, hanem erre az alapzatra vetítödnek rá a különbözö rétegek és bonyolult hálózatok, amelyek materiális formában jelennek meg (pl. utak). A társadalmi térstruktúrák nem megmagyarázhatóak csupán ezek segítségével, mert a materialitásuk mögött létezik valami, ami mindegyikben benne van, és mégsem „dolog”, amely szükséges elöfeltétel, de mégsem meghatározó elem. Ez a tér, amely materiális prekondíciókkal nem definiálható, amely a cselekvések, az interakciók, a hatalmi effektusok és a diskurzusok tere. Az absztrakt társadalmi kapcsolatoknak nincs szükségszerü materiális vetületük, de minden létrehozott térstruktúra (hálózat, kapcsolatrendszer) szolgál valamilyen célt, amely a transzcendentális tudattal kapcsolatos.

A (marxista gyökerű) posztmodern teoretikusok ${ }^{4}$ (pl. F. Jameson, E. W. Soja) és kritikai földrajzosok kiinduló feltételezései is hasonlóak: új társadalmi-gazdasági rend formálódik, amely más térbeli folyamatokat szül. Jameson szerint ma már a 
lényeges folyamatok nem a valóságos fizikai terekben zajlanak, „nincs többé egybeesés azokkal a helyekkel, amit igénybe vesznek" (Jameson 1991, 43), hanem a posztmodern „hipertérben”. Ebben a multinacionális cégek által uralt késő kapitalista globális térben az amerikai kultúra esztétikai populizmusa, térbeli expanziója dominál. De Lefebvre magyarázatához hasonlóan e folyamatok mögött is a termelési mód változása húzódik meg, csak Jameson rávilágít arra, hogy jelen (posztmodern) körülmények között miben más a termelés jellege.

Soja (1989) a jelenleg folyó urbanizáció, regonalizáció és specializáció vizsgálatából indul ki. Megállapítja, hogy az egész világon még mindig az ipar a fejlödés elsődleges hajtóereje, amely egyenlötlen területi/regionális fejlödést eredményez. „Jelen időszakra úgy kell tekintenünk, mint a kapitalizmus válság-generálta kísérletére, hogy megóvja a túlélése kulcstényezőit: a szuperprofit szerzés érdekében a különböző termelő ágazatok és cégek közé egymás mellé helyezi a regionalizált lokalitások hierarchiájában a fejlett és fejletlen területeket” (Soja 1989, 184). „A termelési rendszerek területi vetülete sokkal globálisabbá válik, mint valaha is volt, de nagyon erös urbanizációs hatásuk is van a területi ipari komplexumok helyi agglomerálódásán keresztül” (Soja 1989, 185). A posztfordista reindusztrializáció szelektíven történik, amely egyes régiók hanyatlását eredményezi, míg máshol új ipari komplexumok jönnek létre. A ,'regionális harc a munkahelyekért és a dollárokért' (Goodman 1979) egyre több közösségi forrást szív föl, amelyet a városi és a regionális tervezési eljárás ural" (Soja 1989, 186). ${ }^{5}$

A regionalizáció mozgatórugóit tekintve a materialista, marxista gyökerủ megközelítések mára sajátos ellentmondásba kerülnek. A globalizációra, a szupraregionális europanizációra magam is csak marxista gyökerü magyarázatot tudok adni, és elfogadom, hogy megváltozott a kapitalista termelési mód, amely más típusú térben zajlik. Csak ez az új típusú posztfordista késő kapitalista globalizálódó gazdaság nem a helyi és a nemzeti szint közötti régiókban gondolkodik és egyáltalán nem célja a regionális-kulturális identitás erösítése, újabb regionális határok meghúzása. Ellenkezöleg, mindenféle ligatúra, határ lebontására törekszik, amely a tőke és a munkaerő szabad mozgása ellen hat.

A jelek, kódok, fogyasztási minták „termelése” és közvetítése nem szükségszerüen jár a fizikai térben történỏ mozgásokkal (Faragó 1991), ezek elöállítása nem leképezhetỏ zárt egységet képezỏ régiókban. A globalizálódó gazdasági folyamatok nem a tér fregmentálódása és strukturalizálódása irányába hatnak, hanem éppen ellenkezőleg a homogenizálódás, a határok lebontása irányába, és csak a gazdaságilag semleges, vagy a globális trendek számára érdektelen szférában meglévő nemzeti, területi különbségek fennmaradását teszik lehetővé. A neoliberális gazdaságpolitika, az uniós felzárkóztatási programok „fogyaszthatóvá” teszik az országokat (nemzeteket) és a belső területi egységeket, az ott élő ,humán eröforrásokat” a globalizáció (europanizáció) számára. Napjainkban a nagyléptékủ és kisléptékủ terek és a globalizáció által érintett és le nem fedett területek megkülönböztetésének van elsödleges jelentősége, és nem a nemzeti szint alatt lévő regionális felosztásnak (Faragó 2003). E konstellációban a periferikus helyzet gyakran a globalizációs 
hálózatból való kimaradásként értelmezhető. Az elmaradott területek felzárkóztatásának nem a szolidaritás az indítéka, hanem a globalizáció fizikai és humán előfeltételeinek a megteremtése.

\section{A „létezett szocializmus" regionalizmusa}

Lenin és Sztálin a központi politika gyakorlati érvényesítésének eszközeként tekintett a területi-gazdasági komplexumokra. A szovjet rajonírozási elméletek már a húszas években hangsúlyozták, hogy a termelési komplexumok önmaguktól nem alakulnak ki, azokat tudatosan és tervszerúen kell létrehozni, amely során figyelembe kell venni a természeti és a közgazdasági törvényszerüségeket is. Koloszovszkij (1969) meghatározásában a termelési komplexum - a mai klaszterekhez hasonlóan - olyan különbözö ágazatokhoz tartozó vállalatok együttmüködése, amely egy lehatárolható területi egységen belül koncentrálódik. Szjomuskin (1977) a területi irányítás fontos funkciójának tartotta az ágazatközi fejlesztések összehangolását.

A Szovjetunióban a gazdasági körzetesítések (regionalizáció) során az alábbi szempontokat vették figyelembe (Krajkó 1987):

- Minden körzet a társadalmi-gazdasági adottságainak megfelelően specializálódik.

- A körzeteknek a szakosodás mellett komplexeknek is kell lenniük, biztosítani kell az ágazati kapcsolatok lehetőségét.

- Minden gazdasági körzetnek van egy vagy több központja.

- A gazdasági körzet mint társadalmi képzödmény nem függetleníthetö a természeti, földrajzi adottságoktól.

- A gazdasági körzetek kijelölésénél is szempont a nemzetiségi határok figyelembevétele.

- A gazdasági és a közigazgatási körzetek határai lehetőleg ne térjenek el egymástól.

- A gazdasági körzetek kijelölésénél figyelemmel kell lenni a településhálózatra, a munkaerö-gazdálkodásra, a terület történelmi múltjára, hagyományaira és kulturális életére is.

A fenti szempontok alapján többszintủ tervezési-gazdasági (regionális) rendszert alakítottak ki. Regionális tervek készültek a nagyrégiókra (pl. Szibéria), a területi termelési komplexumokra, az oblasztyokra és a szövetségi köztársaságokra is. Krajkó (1987) szerint a Szovjetunióban ez a „regionalizált” gazdaságfejlesztés a területi kiegyenlítés irányába hatott.

A szocialista regionalizáció folyamatosan napirenden volt Magyarországon is. Fürst már 1954-ben (!) a regionális tervezésröl írt tankönyvében kifejtette, hogy Magyarországon is a létező, így megismerhető régiók egyben a gazdaság irányításának és a tervek végrehatásának a területi egységei. A „...tudományos megismerés arra vezet, hogy a regionális egységeket, mint objektív és a valóságban létező jelenségeket ismerjük el. Láttuk azt is, hogy a különböző kritériumok szerint más és 
másfajta regionális egységeket állapíthatunk meg, melyek általában nem fedik egymást. Minden államnak azonban szüksége van olyan területi beosztásra, mely a közigazgatás hatékony és előnyös megszervezését biztosítja. ... Láthatjuk, hogy a magyar területi beosztás a régi megyerendszer alapján, ma már nem felel meg a szocializmus építésének és meglehetősen sok súrlódást is okoz, annak ellenére, hogy egyes kirívó hibákat a régi megyehatárok megváltoztatásával már megpróbálták orvosolni. ... Az első ötéves terv ... többek között célul tüzte ki a magyar ipar decentralizációját. Ennek az elmaradott területek fejlesztését, a város falu közötti ellentét felszámolását, de egyszersmind a termelés fokozását és gazdaságosságának emelését is kellett volna eredményeznie. ... Mindez azért van így, mert hiányzott és még ma is hiányzik a regionális tervezés. Az a feladat, hogy a népgazdasági tervünket - és a terv törvény - meg is valósítsuk, azaz területileg is felbontsuk" (Fürst 1954, 10-12). A ,....különböző történelmi korokban, különböző természeti erök által jellemzett területeken az emberek teljesen eltérő kultúrákat építettek fel, és viszonylag egyedülálló szervezeteket és berendezéseket a célból, hogy régiójuk forrásait legcélszerủbben felhasználhassák. ... A régió olyan összefüggő földrajzi és gazdasági területegység legyen, amely közös, jellegzetes természeti adottságokkal, ezekhez mért népsürüséggel, kellő szervezetséggel olyan általános és politikai kultúrával bír, ami a népgazdasági terv révén a reá kiosztott szerepnek a lehető legjobb betöltésére képesíti. Evvel nemcsak a saját, hanem az egész ország lakosságának életszínvonalát a leghatékonyabban emeli" (Fürst 1954, 60; 63). Helyettesítsük be az 1954-ben írott szövegbe a népgazdasági terv helyébe a nemzeti fejlesztési tervet, a gazdaságosság emelése helyébe a versenyképesség fokozását, a termelési komplexumok helyett a gazdasági klasztereket stb., és azzal szembesülhetünk, hogy a regionalizációnak, a régióknak ma szánt szerep sem tér sokban el a centralizált pártállamban nekik szánt szerepkörtöl.

\section{Az európai „új regionalizmus”}

A régiók a hatvanas, hetvenes évek Európájában sem kaptak nagyobb figyelmet a területi és politológiai kutatásokban, mint nálunk, viszont a nyolcvanas évektöl, az új regionalizmus, a „régiók Európája” gondolat megszületésétől a gazdaságfejlesztés és a területi tervezés középpontjába kerültek. Ezzel az országok belsỏ térfelosztásának kérdése részben átkerült a nemzetközi diskurzustérbe.

A globalizáció erősödése, a neoliberális gazdaságpolitika térnyerése és az európai integráció következtében a nemzeti szintü fejlesztéspolitika befolyása mérséklödött, az állami beruházások csökkentek, amelyek olyan alternatív fejlesztési teóriák, paradigmák megjelenését és érvényesítését eredményezték, amelyek a hagyományos helyi és regionális gazdaságokra, azok kapcsolataira, hálózataira építettek. Sokan úgy gondolták, hogy az erösödő ,,provincionalizmussal” ellentétben az új neoliberális gazdaságpolitika „új teret” igényel. Ezért az európai új regionalizmus a tér ủj paradigmára épülö átstrukturálását tüzte ki célul. A tradicionalizmus felelevenítése nélkül kívánták kihasználni az újabb térszerveződésekben rejlő elönyöket. 
Az új (utópikus) regionális terekben a funkcionális szereplök bizonyos kérdésekben - nemzetállami ellenörzés nélkül - szabadon dönthetnek, és az új régiók a versenyképességük javításával hozzájárulnak az európai gazdaság erősítéséhez.

Az európai új regionalizmus keresztapja, Keating (1998) is a fizikai teret tartja a területi megközelítés központi tényezöjének, amely önmagában is hatással van a gazdasági tevékenységekre, a társadalmi integrációkra és az élet menetére. Az ebböl következö földrajzi determinizmust úgy próbálja elkerülni, hogy hozzáteszi, a fizikai környezet nem determinálja, hanem feltételeit biztosítja a társadalmi interakcióknak, és csak ezzel nem magyarázható a tér mint politikai tényezó. Ebben a szélesebb értelemben a teret történetileg változó politikai konstrukciónak tartja, amely a környezet, a gazdaság és a politikai intézmények kölcsönhatásának eredményeként létrejövő sajátos entitás. A régió mint speciális térkategória Keating (Richardson, Hoover, Isard stb.) számára is a legnehezebben megragadható, így gazdasági, társadalmi, kulturális tartalma oldaláról írja körül annak különbözö nagyságú és szintủ kategóriáit. Tehát annak ellenére, hogy a fizikai teret tartja a társadalmi-gazdasági strukturálódások egyik okának, nála is a térhasználatoknak vannak régiói, amelyeknek meghatározhatóak az eltérö fizikai vetületeik (területeik és határaik). A régiót inkább nyitott politikai rendszernek tartja, mint önmaga által meghatározott egységnek. A régiók más területi szintekkel funkcionális kapcsolatban lévö részleges társadalmi egységek, így a regionalizmus nem alternatív államszervezési elv, a régiók nem vehetik át az állam funkcióit! Létezésük az állami feladatok ellátásának módjára hatnak és módosítják a nemzetállam hatalmi struktúráját. „A régiókra úgy tekinthetünk, mint területi határokkal rendelkezỏ társadalmi konstrukciókra ... a regionalizmus társadalmi, gazdasági és politikai tartalma a politikai folyamatoknak megfelelöen változik" (Keating 1998, 13).

Az új regionalizmusnak kétségtelenül van számos funkcionális mozgatórugója (pl. gazdasági átalakítás, többszintủ kormányzás), de én sokakkal ellentétben nem a nemzetállam válságával vagy a posztmodern körülményekkel magyarázom, hanem inkább a fejlesztéspolitika, a támogatáspolitika megváltozásával. A kormányok vesztettek gazdaságirányítási hatáskörükböl, így nem tudták már megfelelöen kontrollálni a területi fejlödést sem. Sokan úgy gondolták és gondolják még ma is, hogy a hagyományos provincionalista helyi gazdaságfejlesztés nem kínál megfelelő kereteket a gondok orvoslásához, a modernizációhoz. A vállalatok versenyképessége egyre nagyobb részben fủgg a külsö gazdaságosságtól. A globális piacon történő mind jobb helytállás érdekében történö gazdasági átalakítás, a versenyképesség javítása egyre inkább a regionális szinten meglévő gazdasági tényezők különbözö kombinációitól függ. Ha a kormányok a megfelelö makrogazdasági kereteket kialakították, a szükséges országos infrastrukturális hálózatokat kiépítették, nem marad több eszközük a regionális gazdaságok ösztönzésére. A föderalista, a regionalizált államok kormányainak nincs direkt beavatkozási lehetőségük a regionális tartalékok aktivizálására, a humán töke fejlesztésére, így a megoldást az új regionalizmusban látták, látják. Az új paradigmát a területi szolidaritásra, a területi alapú tervezésre és cselekvésre kívánták alapozni, de a megvalósitás kulcskérdése az országon belüli 
döntési hatalom újraosztása. Ez nem okozott gondot azokban a decentralizált országokban, ahol a régiók már integrálódtak a közigazgatásba, és a regionális intézmények megfelelỏ hatáskörökkel rendelkeztek. De a hatalmi rendszer átstrukturálása nemcsak nálunk, Magyarországon ütközik nehézségekbe (és általában az újonnan csatlakozó országokban), hanem mindazokban a nyugat-európai országokban is, ahol új regionális szint kialakítását szorgalmazza az Európai Unió. A központi (nemzetállami) kormányzás kompetenciákat és forrásokat adott át a szupranacionális szintre, veszített hatalmából a magánszférával szemben is, és most új aktorok, a régiók szeretnének kiharcolni maguknak jogköröket és forrásokat.

Magyarországon a térstruktúra újraalakítása körül folyó hatalmi harc nyíltsisakos megvívását nehezíti, hogy az egyik (regionális) fél még csak alig állt fel, fegyverzete hiányos, nincs a regionális identitáson alapuló elkötelezettsége, inkább csak a kitűzött díjért (regionális támogatásokért) száll harcba, mint meggyőződésből. A csata igazi tétje a decentralizáció, de kimenetelét befolyásolja, hogy a központ zászlaja alatt harcoló fél álítja fel a szabályokat és a „regionális” csapatot is, fizeti annak zsoldosait és a fegyverzetét is.

Több nemzet gyakorlatában az európai új regionalizmus nem vezetett új térkategóriák kialakításához, hanem az új funkciókat a már mủködő intézményi struktúrába integrálták. Elöre nem kalkulált gyakorlati fejlemény, hogy a nemzetállamok a szupranacionalizmus és a regionalizmus kapcsán elszenvedett veszteségeiket úgy kívánták enyhíteni, hogy jelentős szerepet vállaltak a regionális intézmények létrehozásában, a partnerség kiépítésében, a finanszírozásban stb., amely az irányítási, a hatalmi pozíciók megtartásával járt. Az új intézményrendszer kialakítására a kohéziós országokban hathat a legnagyobb mértékben az Európai Unió, hiszen a támogatások megszerzésének feltételei közé sorolhatja azokat. De ezek az új régiók nem alulról építkezve, természetes fejlődés során jönnek létre, nem szabadnak születnek, nem ök döntik el, hogy mik lesznek, ha megerösödnek, hanem egy szigorú hierarchiába, müködési rendbe illeszkednek, nekik szánt bizonyos funkciók ellátására hozzák létre öket! Intermedier helyzetük és közvetítö, végrehajtó szerepkörük nem hagy teret saját identitásuk megtalálására, kialakítására.

A globalizációt mozgató gazdasági erök egyre inkább és egyre több helyen átveszik a politika irányítását. Egyre inkább úgy tủnik, hogy az európai új regionalizáció csak egy naiv kísérlet (volt) arra, hogy területi szinten hatást gyakoroljon a gazdaságra. A gyakorlatban éppen a fordítottja történt: a regionális politika is egyre tisztább formában - beállt a neoliberális gazdasági racionalitás szolgálatába. A regionális versenyképesség feltételeinek erősítésével azokat a területeket is alkalmassá kívánják tenni a globális európai gazdaságba való bekapcsolásra, amelyek a külső gazdaságosság biztosításához szükséges feltételek hiányában kimaradnának abból. E minimális feltételek megteremtése után ez tovább már nem mozgatóereje az európai uniós regionalizmusnak. A gyakran provincionalizmussal vádolt hagyományos (még újabb) regionalizmus sokkal inkább szolgálhatja a decentralizációt, a területi érdekek érvényesítését, a területi értékek védelmét, a másság fenntartását, amely ütközik a jelenlegi törekvésekkel. 


\section{A regionalizáció alternativ értelmezésének alapjai}

A tér semmi és minden. Nem tárgy, hanem olyan megismerési forrás, amelyből többek között a tárgyak állnak, de nem határozza meg azokat anyagi valóságukban, mert csak a lehetséges formájukat adja. Térfelfogásunkat sajátos kettösség határozza meg: a tér egyrészt a rajtunk kívủli tárgyaktól független tiszta szemlélet, gondolati konstrukció, másrészt minden létezö sine qua nonja, formája, kerete; egyrészt absztrakt (,„szubjektív”) rendezöelv, a priori képzet, másrészt konkrét (,objektív”) tapasztalati elemekböl álló gyakorlati konstrukció (Kant 1981).

Az önmagában vett (szubsztanciális) tér megfoghatatlan, érzékelhetetlen, egyforma „sủrüségü" üres forma, amelyben elrendeződnek és elrendezzük a jelenségeket. $A z$ üres tér önmagában nem strukturálódik, a nem-lét terében nincsenek kitüntetett pontok, amelyek körül a jelenségek szükségszerủen szerveződnek vagy szervezhetők.

A gyakorlatban viszont nincs üres tér. A lét-tér a magánvaló világ tárgyain kívül tele van minőségekkel, értékekkel, utópiákkal, ítéletekkel, törekvésekkel stb. $A$ számunkra adódó tér mindezek együttlétezésének rendje, fizikai és/vagy virtuális hálója. A tér folytonos, és így az együtt létező elemei szükségképpen kölcsönhatásban vannak. A legtöbbször ,területi (regionális) hatásként” aposztrofált komplex jelenség az együttlétezésböl következö szükségszerü kölcsönhatásra utal. A különböző téregységekben - így a régiokban is - a legkülönfélébb faktorok sajátos együttlétezése tapasztalható, amelyek sajátos feltételeket és lehetőségeket teremtenek a tényezők közötti interakciókra. Nemcsak a természeti-gazdasági körülmények mások a különbözó régiókban, hanem a kulturális-politikai különbségek és az azokhoz való elkötelezettség következtében azok megítélése és kezelésének módja is más lehet, ami ugyancsak hatással van az ott mủködő gazdasági egységekre.

A területi struktúrák egyrészt a használatból következỏ viszonyrendszerből erednek, másrészt a céljainkhoz kapcsolt térkoncepciónknak megfelelően folyamatosan alakítjuk azokat. A priori térszemléletünk történetileg változó. Korábban meghatározóak voltak tapasztalatainkhoz kötődő érzeteink, mára egyre inkább képesek vagyunk ettől elvonatkoztatni. A mindennapi életben a térről alkotott képünket leginkább az experimentális földrajzi tér és annak használatához kapcsolódó fogalmak, mint nyelvi eszközök határozzák meg, és ez az az előzetes tudás, amelyben a jelenségek térértelmezése interpretálódik, és amelyben, mint elöfeltételezésben a különböző térbeli összefüggéseket konstituáljuk, amelynek megfelelően cselekedeteinket térben szervezzük.

A posztstrukturalisták, a posztmodernek (pl. Derrida, Lyotard, Thom) a teret nem a newtoni értelemben szemlélik, hanem politikai-gyakorlati konstrukciónak tartják. Szerintük, mint élettérnek van értelme, és nem mint önálló, a szubjektumtól független tartománynak. A tér és annak elemei (pl. régió) nem személytelen, hanem interpretált kategóriák.

A nyelv szerepét, a nyelv a priorit (pl. Wittgeinstein, Searle) hangsúlyozók, arra hívják fel a figyelmet, hogy a nyelv nem pusztán a tények leírására szolgál, hanem a térfogalmak használata maga is alakítja a teret, a területi intézményeket és a 
majdani térhasználatot. Az aktuális térhasználatnak megfelelö térfelosztást szavakkal/kódokkal írjuk le (szoba, utca, piac, város stb.). A mindennapi használat során ezek a szavak dekódolhatók, értelmezhetök, és arra is alkalmasak, hogy segítségiük. kel új térhasználatokat definiáljunk, magyarázzunk és fogadtassunk el, sőt a valóságban létre is hozzuk azokat. De a térkategóriákat jelölö szavaknak nincs egyértelmü metakód érvényük, nem bírnak mindenhol azonos elöíró értelemmel, csak a praxisban kialakult sajátos használatának megfelelő olvasatuk, értelmezésük létezik. Tehát egy olyan országban, mint Magyarország, ahol az embereknek nincsenek személyes regionális tértapasztalataik, nincs regionális identitásuk, a tudományos érvelés és a politikai akarat (intencionalitás) által vezérelt nyelvi kommunikáció segítségével alakul ki bennünk a „régió" jelentése/tartalma, és megy át a „valóságba", mint intézmény. Ezért nem szerencsés, hogy bizonytalanságra ad okot a „régió", a „regionális" fogalmak nem egyértelmủ használata a magyar tudományos nyelvben, és különösen hátrányos a regionalizmus számára, hogy a politikai retorika és a területfejlesztés gyakorlata ellentmond egymásnak. Mivel a régió nem megtapasztalható valóságelem, és ma még nem az életvilágunk része, így különösen fontos lenne a jobb tudományos megalapozás és a szélesebb körü nyelvi gyakorlat, ha valóban új típusú régiókat szeretnénk kialakítani. Jelenleg nem diskurzus folyik a régióról, hanem egyirånyú kommunikáció sarkall egy idea gyakorlati adaptációjára, így e folyamat nem vezethet interszubjektíven osztott tudáshoz és közös meggyőződéshez, ezért a különféle szereplők várhatóan hosszabb távon is meg fogják kérdőjelezni a hatalmi effektusok révén érvényesített parciális tudást és az az alapján létrejövő regionális intézményeket.

Nem mindenki vesz részt egyformán a nyelvi kommunikáció segítségével a téralakításban. Vannak aktívabb személyek, csoportok, de a nagy többség csak fogyasztója, alkalmazója az új jelenségeknek. Magyarországon például a térbeliség kiemelt kezelésében, a regionalizmus, a régió fogalmának adaptációjában és az intézményi világban történö megjelenítésében a kilencvenes évek elején a tudomány jelentős szerepet játszott, ${ }^{6}$ majd a politikusok csatolták fogalomtárukhoz a kapcsolódó fogalmakat, és a sajátos politikai gyakorlatnak megfelelỏen átalakult a fogalmak tartalma. A jelenlegi diskurzus különböző szereplői saját térkoncepciójuknak megfelelö jelentéssel igyekeznek megtölteni a régió fogalmát. Az európai új regionalizmus eredeti szándékával ellentétben a régiók nem új hatalmi tényezők lettek, hanem a korábbi szereplö́k (a kormány, az ágazatok, a megyék, a politikai pártok stb.) a saját érdekartikulációjuk újabb színtereként „használják” azokat. Az Európai Unió képviselői/szakértői a számukra jobban kezelhető homogenizált ideát igyekeznek közvetíteni, a különbözö szinteken müködỏ politikusaink olyan régiót támogatnak, amely nem vesz el tölük hatalmi jogosítványokat és anyagi forrásokat, hanem az ö érdekeiket szolgálják.

A térben egymás mellett létező jelenségek egymáshoz füződő viszonyaik, kapcsolataik alapján különböző elrendeződéseket (rendezettség), térstruktúrákat alkotnak. A jelenségekben felismerhetök általánosítható területi szabályszerüségek, és meghatározhatók területileg eltérő különbségek is. A regionalizáció megerősítheti a 
korábbi térhasználatokat, és ezek objektivációit (konzervjeit), de a tapasztalatok és a törekvések (célok) függvényében változtatásokat kezdeményezhet. Az emberi cselekvések nyomán létrejött regionális intézmények és struktúrák idővel elválhatnak az őket létrehozó térhasználattól, és olyan „külső adottságot” jelentenek, amelyekhez alkalmazkodni célszerü, amelyekkel az újabb cselevések megtervezésénél számolni kell. A kialakult, már létezỏ térstruktúra a társadalmi-gazdasági kapcsolatoknak, a politika formálásának is - fizikai és átvitt értelemben is - határait, kereteit, esetenként korlátait adja.

A különböző használattal, funkcióval rendelkező területi szintek az egymásba illeszkedés okán vertikális hierarchiát alkotnak. Az emberek és közösségeik felöl, alulról épített térstruktúrában a magasabb szint létezése mindig a kevésbé átfogó alacsonyabb szintekben gyökerezik! Az alacsonyabb szintek a magasabb (összetettebb, bonyolultabb) szintek átfogóbb, általánosabb müködési elveinek keretein belül müködnek. Az alsóbb szintủ entitások autonóm szükségletei behatárolják a felsőbb szintű entitás hatókörét. Tehát minden szint a saját és a magukból alkotott magasabb szintek törvényszerüségei szerint müködik. A felsőbb szintek müködése nem magyarázható kizárólag az alsóbb szinteket alkotó egységek működése alapján, minden szintnek saját müködési elvei (törvényszerüségei) és funkciói vannak. A magasabb szintet saját müködési elvei szabályozzák, ugyanakkor nyitva hagyják az alsóbb szintek müködési tereit.

A régiók mint a térstruktúra mesterséges, adminisztratív elemei nem szükségszerủen a reálfolyamatok leképezései, hanem igen gyakran az adott kontextusban lefolytatott társadalmi diskurzusok eredményeként létrehozott térreprezentációk. A diskurzusokat néha lezárják, és ott és akkor megnevezésre, elfogadásra és kialakításra kerïl egy a plauzibilis megoldások közül. Az adott pillanatban a regionális intézményrendszerbe merevített térstruktúra külsö „,erőszakot” jelent az állandóan változó, kaleidoszkópszerủ térformációkat alakító társadalmi-gazdasági folyamatok számára. De a későbbiekben a különböző szereplök mủködésüket az így kialakított „ „tényhez” igazítják, így utólag felfedezhetők az ezekhez köthető szabályszerüségek.

A területi határok a társadalmi gyakorlatban és a politikai diskurzusban gyökereznek, szimbólumokat és intézményeket jelentenek (Paasi 2001). Az emberek a térhasználatuknak megfelelően megkülönböztetés, elkülönítés, a különböző viszonyok kezelése, irányítása érdekében, értékek és érdekek védelmére (mesterségesen) területeket határolnak le, falakat, kerítéseket emelnek, politikai, igazgatási határokat húznak, felosztják a teret. A térfelosztással saját cselekedeteiknek kívánnak jobb kereteket adni, térbeli létük hatékonyságát kívánják növelni, vagy csak átláthatóbbá, kezelhetöbbé, regisztrálhatóvá akarják tenni a társadalmi fizikai jelenségeket. Ezzel megteremtik a belső-külső, a befogadås és kirekesztés kettősségét, a határsértés és a kritika lehetőségét. A határok az azonosulás és elutasitás mezsgyéi, amelyek két perspektívát és két le gitimációs teret is létrehoznak. Ilyen demarkációra csak akkor van szükség, ha hatalmi struktúrák között húz vonalat, vagy valamilyen célt szolgál, haszonnal kecsegtet a megkülönböztetés, az elkülönülés vagy elkülönítés, ha valamit másoktól meg kell védeni, vagy valamit a kívülrekedtekkel szemben érvényesíteni 
akarnak. A regionális határok meghúzásakor számolni kell azzal is, hogy ezzel újabb korlátot, újabb hierarchikus elemet hozunk létre, új konfliktusokat teremtünk, amely számos természetes folyamatot korlátoz. Egyre többen adnak hangot véleményüknek (pl. Paasi, Massay), miszerint a térelemek sok esetben nem szigorúan körülhatárolt területek (territory), sokkal inkább nyitott társadalmi-politikai terek. ${ }^{7}$

A szándékunknak megfelelően a régiót kialakíthatjuk az új interakciós folyamatok (tóke, információ stb.) állandóan változó kozmopolita terében, és a történetileg alakuló hagyományos, partikuláris helyek strukturrájában is (,space of flows, space of places", Castells 1999). Önkormányzati hatalommal nem rendelkező, gazdaságfejlesztési, promóciós feladatokkal felruházott regionális intézmény mủködése nem szükségszerüen szorítandó fix határok közé. A folyamatok csomópontjában, a székhelyén dolgozó, megfeleló jogosítványokkal felruházott intézmény mindenkori múködési terullete rugalmasan igazodhatna az aktuális folyamatokhoz, így elkerülhető a fix határok korlátozó hatása. Ha nem a határokra, hanem a feladatokra koncentrálunk, akkor rugalmasabb, hálózatszerü müködés alakítható ki. Az ország teljes területét átfedésmentesen lefedő regionális struktúrára, a hagyományos „helyekböl felépített térre" az alábbi esetekben van szükség: ha a régió integrálódik a közigazgatásba, ha statisztikai egység, vagy ha közvetítöi szerepet kap a források újraosztásában, azaz az ellátásban, az intézményfenntartásban, a tervezési rendszerben. Ezek a régiók hagyományos szerepköröket tölthetnek be, alkalmasabbak a teriuleti közösségek és értékek újratermelésére, az összetartozás erösítésére, mint az új (globalizációs) folyamatokba való bekapcsolódás elösegítésére.

Tehát a mikro-, mezo- és makrorégiók nem objektív fizikai térkategóriák, a regionális jelenségek nem egy általánosabb szubsztancia, a térbeliség eredöi, még csak nem is az állandóan változó és eltérỏ területiséggel bíró reálfolyamatok egyszerü leképezése, hanem politikai intézmények, így nem szükségszerüen, mindenkor és mindenhol léteznek és nem uniformizálhatók. Ritkábban az eleve meglévő tartalmuk, sokkal inkább eszközjellegük felöl közelíthetỏ sajátos térszerkezeti egységek. A különböző regionális térfelosztások, klasszifikációk jól demonstrálják az eszközjelleget. A régiók lehetnek a tudományos megismerés vagy az akarat véghezvitelének (hatalomgyakorlás, irányítás, piacszervezés stb.) eszközei is. A régiók, a regionális intézmények társadalmi konstrukciók, kialakításuk nyelvi természetủ. Hatalmi-társadalmi diskurzusok révén kerülnek meghatározásra, és egyeznek meg jelentésükben (tartalmukban). A kollektív elfogadás és használat legitimálhatja és az észlelt valóság, az élettér részévé teheti azokat, vagy módosíthatja a jelentést!

A régióknak csak akkor van per se tartalmi vonatkozásuk, akkor önálló entitások, ha a zárt földrajzi egységben élő népességének olyan, a környezetétől különbözö, sajátos és közös jellemzői vannak (pl. nyelv, kultúra, történelmi tradíció, sajátos gazdaság), amelyeket szeretnének megőrizni és fejleszteni, azaz sajátos társadalmigazdasági folyamatok termelödnek újra ezekben az egységekben, és a közös értékek és érdekek a közös akarat és cselekvés alapját képezik. Ez a kulturális-területi identitás által meghatározott tér Magyarországon a nemzetállam. Ha az országot több ilyen egység alkotná, akkor szükség lenne arra, hogy a regionalizáció a területi 
önigazgatást célozza meg, választott önkormányzatot alakítsunk ki. Ezek hiányában csak akkor célszerülésszerü kialakítani nagyrégiókat, létrehozni regionális önkormányzatot, ha léteznek olyan problémák, feladatok, amelyek az alacsonyabb szinteken hatékonyan nem megoldhatók, azon túlnőnek, és azt az alsóbb szint szereplöi be is látják. Az így létrejövő mikro-, mezo- és makrorégiók (pl. kistérségek, megyék, nagyrégiók) a közös belső értékek, érdekek védelmét szolgálják, és saját politika kialakítását, hatékony megvalósítását segíthetik.

A formális régiók feliullröl való létrehozására és intézményesítésére (dekoncentráció) elsösorban a központi feladatok hatékonyabb teljesítése érdekében lenne szükség. Ez esetben elég lenne dekoncentrált állami hivatalokat létrehozni. De a szubszidiaritás elvén alapuló regionalizáció a decentralizációt tủzi ki célul, amely a hatalom újraosztását jelenti. De a hatalom természetéből következően a központi szervezetek nem adják le önként döntési-hatalmi kompetenciájukat, így a tényleges decentralizáció csak az országon belüli hatalmi harc eredménye lehet.

A tervek szerint a hatalmi rendbe való beépüléssel a regionális intézmények felhatalmazást kapnak a környezeti, a gazdasági gondok kezelésére, irányítására. Számos jel arra utal, hogy feladatuk részben az lesz, hogy a hatáskörükbe tartozó szereplöket, azok rendelkezésére álló fejlesztési forrásokat eszközként használhassák a magasabb szinteken megfogalmazott és az alsóbb szinteken elismert szükségletek teljesítése érdekében. Félő, hogy a felülről vezérelt uniformizáló technikai racionalitás uralmi eszközévé válnak az ilyen céllal és módon kialakított régiók. Fennáll annak is a veszélye, hogy a jelenlegi csatornákon keresztül csöpögtetett támogatások narkotikumként szolgálnak az alsóbb szintek számára, olyan függöséget eredményezve, amely az „eszköz” fenntartásának támogatóivá teszi öket (lásd például az EU ,phasing out" régióit).

\section{A magyar regionalizáció dilemmái}

A 20. században Magyarországon a közigazgatási rendszer alapvetỏen háromszor változott meg: az első és a második világháború után, valamint az 1990-es rendszerváltás kapcsán. ${ }^{8}$ Ezek közül az elsö járt a térszerkezet radikális átalakításával, míg az utóbbi kettő esetében az ideológiai, politikai változások játszották a döntỏ szerepet. E töréspontokhoz köthetö reformokon kívül folyamatosan napvilágot láttak hazai elképzelések a térstruktúra megreformálására, régiók kialakítására, de a gyakorlatban jelentős változások mégsem történtek.

A gyöztes hatalmak (vélt vagy valós) stratégiai érdekeit tükröző trianoni szerződés alapvetően rajzolta át a magyar térstruktúrát. A harmadára zsugorodó országterület megváltoztatta a településhálózatot, a megyehatárokat, az etnikai összetételt, semmit sem hagyott érintetlenül. A két világháború között számos regionalizációs elmélet és javaslat látott napvilágot, ${ }^{9}$ többségük Magyarország hét régióra való felosztását javasolta, de egyik sem ment át a gyakorlatba. Egy kisebb változtatástól (1929) eltekintve az 1923-as közigazgatási rendszer stabil maradt. ${ }^{10}$ Mindegyik regionalizációs koncepció hangsúlyozta, hogy az új országhatárokon belül elvesz- 
tették jelentőségüket a nemzetiségi és a kulturális szempontok, így más racionális szempontokat kell mérlegelni.

A második világháborút követő párizsi békeszerzödés visszaállította az 1937-es országhatárokat, így a Szovjetunióból importált tanácsrendszer kialakítása elsősorban a meglévő térstruktúra "tartalmát" alakította át, és csak kisebb térszerkezeti korrekciók történtek. A „szovjet blokk” intézményrendszerében kivülröl irányított politikai változások zajlottak le, a nemzeti sajátosságok rovására uniformizálódás irányába történt elmozdulás. A rendszerváltó folyamat zárására kialakult a mai megyerendszer (1950), és ezt követỏen csak minimális változások történtek közigazgatási rendszerünkben. A folyamatosan napirenden lévő szocialista regionalizációs (rajonírozási) javaslatok nem jártak sikerrel, és a javasolt régiók nem integrálódtak a magyar közigazgatási struktúrába.

Az 1949-ben létrehozott Területrendezési Intézetben volt önálló Regionális Tervező Osztály. Az ötvenes évek első felében a pártpolitika és az eröltetett ütemü „szocialista iparosítás" rányomta bélyegét a területi tervezésre, de 1956-ot követően számos szakmai indíttatású regionális vizsgálat és terv készült. Ezek közül a Balatoni Regionális Terv nemzetközi elismerésben is részesült (Abercombie-díj). A területi tervezésröl 1958-ban elfogadott kormányhatározat (2030/1958.) regionális vizsgálatok és tervezés folytatását irányozta elő kilenc nagyrégióban. A tervezést három munkaszakaszra osztották: vizsgálat, koncepció és rendezési terv. 1963-ban a regionális tervezés új rendszerét vezették be (1011 és 1012/1963. kormányhatározat). Magyarország Településhálózatfejlesztési Tanulmányterve (1965) a korábbi elveknek megfelelően három központi (budapesti, szolnoki és székesfehérvári) és hat periferikus (miskolci, debreceni, szegedi, pécsi, nagykanizsai és győri) nagyrégiót jelölt ki. Az 1971-ben elfogadott Országos Településhálózatfejlesztési Koncepcióban azok a nagyvárosok kaptak felsőfokú központi rangot, amelyek vonzáskörzete (régiója) 1-1,5 millió lakosra terjedt ki. Még abban az évben megkezdték a hat tervezési gazdasági körzet középtávú fejlesztési koncepcióinak a készítését. Ez az ország egészét lefedő - mai fogalmaink szerint NUTS 2-es szintre történő - regionális tervezés 1973-ban abbamaradt. A késöbbiekben funkcionális körzetekre, régiókra készültek regionális tervek (balatoni üdülökörzet, miskolci és pécsi agglomeráció stb). 1985-ben az Országgyưlés európai trendeknek is megfelelö határozatot fogadott el a terület- és településfejlesztés hosszú távú irányelveiröl (12/1980-1985). Pozitív elmozdulásra utalnak az országgyülési határozatban elfogadott irányelvek:

- A termelőeröket területileg eltérő módon kell fejleszteni:

- jobban figyelembe kell venni a térségi adottságokat,

- erősíteni szükséges a helyi termelési kapcsolatokat,

- tovább kell folytatni a gazdasági fejlödésben elmaradt térségek felzárkóztatását;

- megkülönböztetett figyelemmel kell kezelni a sajátos adottságú térségeket;

- a településrendszert arányosabban kell fejleszteni, jobban elötérbe helyezve a közép- és kisvárosokat;

- foglalkoztatáspolitikai cél; 
- mérsékelni kell a lakosság életkörülményeiben meglevő indokolatlan különbségeket;

- érvényesíteni kell a környezet- és természetvédelmi követelményeket;

- nagyobb súlyt kell helyezni a meglevö települési értékek védelmére;

- erősíteni kell a terület- és településfejlesztés tudományos megalapozottságát;

- és módosítani kell a területi irányítási rendszert.

Az irányelvek végrehajtásának érdekében megkezdték a gazdaságilag elmaradott megyék fejlesztési programjainak az elkészítését és a Területfejlesztési és Szervezési Alap támogatásával azok végrehajtását. Tehát a rendszerváltáskor - a mai besorolásnak megfelelően - NUTS 3 szinten folyt az elmaradottnak minősített területek kormányzati irányítással történő felzárkóztatása. Az 1990-es rendszerváltást követően az uniós integrációs elvekhez igazodóan, de különösebb törés nélkül folyt tovább ez a munka.

Tehát a szocialista praxisban folyamatosan napirenden volt az elsősorban gazdasági tartalmú, magasabb szintủ ellátást biztosító régiók kialakítása, amelyek irányításában fontos szerepet szántak a központi tervezésnek és területfejlesztési támogatásoknak, de e tevékenység mindig megmaradt a területfejlesztés és a területi tervezés hatókörén belül, és a regionális szint sohasem jelent meg a közigazgatásban.

1985-töl folyamatos igazodás történt az Európa Tanács és az Európai Közösség/Unió normáihoz. A praxis által kikényszerített lépéseket megtettük, de mind a mai napig nincs konszenzus a területfejlesztés, a területi tervek hatókörét és a regionalizáció megítélését tekintve.

Ma a regionalizáció elsődleges tudásforrása, a diskurzusok irányítási, hatalmi központja az Európai Unió. Bizonytalanságot jelent, hogy az Európai Uniónak sincs egyértelmü régiófogalma, modellje, ott is folyamatosan alakul az ideálkép, amelytöl minden konkrét nemzeti gyakorlat az adott kontextusnak megfelelően eltér. A magyar tudomány, az aktuálpolitika és a médiák nagyobb részben csak e változó ideálkép közvetítésével foglalkoznak, és kisebb figyelem irányul arra, hogy az európai keretek között megtaláljuk a sajátos magyar megoldást. Természetesen az uniós térről folyó európai szintủ együttgondolkodás más eredményre vezet, mintha a térfelosztásról csupán nemzeti keretek között gondolkodnánk.

Az 1990-es rendszerváltást követően az integrációs impulzusok hatására újabb lökést kapott a magyar regionalizmus anélkül, hogy annak tartalmát tisztázták, újraértelmezték volna. E folyamat magyarországi megítélése (értékelése és értelmezése), okainak megnevezése eltérö. Az EU „hivatalos álláspontja” a különféle politikai és jogi dokumentumokból ismert, ezek magyar interpretációi uralják a magyar szakirodalmat is. E tanulmányok azt sugallják, hogy EU-s integrációnk szükségszerū velejárója a NUTS 2-es régiók kialakítása. A vélemények csak abban térnek el, hogy az egyik tábor elegendőnek tartja a tervezési-fejlesztési-statisztikai régiók létét, míg mások a regionális önkormányzatok kialakítását tartják szükségesnek.

A szerzők többsége - a korábban tárgyalt materialista, marxista alapokon - a saját tudományágának (földrajz, közgazdaságtan, regionális tudomány stb.) megfelelő megközelítésben a reálfolyamatokban keresi a regionalizáció alapjait, és nevezi 
meg (természetföldrajzi tájak, gazdasági klaszterek stb.) az annak leginkább megfelelő területi vetületet. Egyelöre kevesebben vagyunk, akik a magyar regionalizációt nem a reálfolyamatokból eredő szükségszerüségként értékeljük, hanem politikai kérdésként kezeljük. Elismerem, hogy a regionalizáció köthető a racionalizáció marxista Weber olvasatának megfelelően a termelőerök fejlődéséhez, a gazdaság térbeliségéhez ${ }^{11}$ és környezetvédelmi kérdésekhez, de én leginkább a társadalmi irányítás, ellenörzés racionalizációs folyamatát látom benne, ami jó esetben a demokrácia erősítését szolgáló decentralizált államberendezkedés kiépítését szolgálhatja.

A regionalizmus mindenütt - így nálunk is - alapvetően három síkon folyhat: (1) a kultúra, (2) a gazdaság és (3) a politika területén.

1) A valós regionalizáció alapjait Európában a kulturális közösségekben találjuk meg. Európában nagyok a nemzetek és országok közötti kulturális különbségek, és ezekhez képest a trianoni békeszerzódés utáni Magyarország homogén. A régiónak mint terúleti nyelvi kulturális egységnek létjogosultsága van például Belgiumban, Spanyolországban, Nagy-Britanniában, Szlovákiában vagy Romániában, de nem nálunk. Magyarországon belül nincsenek karakteres területi különbségek nemzetiségi, kisebbségi, vallási vagy nyelvi szempontból. Regionális identitás sem létezik, legalábbis a létező területi-kulturális azonosságtudat nem a NUTS 2-es regionális szinthez köthető. A táji különbözőségek ellenére szignifikáns regionális eltérések a munkakultúra és az életvitel vonatkozásában sincsenek. Az életfelfogásban, a globális gazdasághoz való viszonyban is inkább az urbánus-népies törésvonal fedezhető fel, amely inkább egyéni értékválasztást, esetleg politikai elkötelezettséget jelent, amely esetenként település- és kistérségtípusok közötti különbségekben ragadható meg. Tehát Magyarországon sokkal nagyobbak a különbségek a főváros és a fővároson kívüli területek, a városok és falvak, az urbánus és rurális kistérségek között, mint bármelyik más területi metszetben. Így a területi identitás vagy sajátos (területi) politikával való azonosulás is inkább ezekben a területi metszetekben képzelhetö el.

Az átlag magyar kognitiv térképén sem jelennek meg a NUTS 2 típusú régiók. Nemcsak a tájékozódási vagy azonosítási térképról hiányoznak, hanem metaforikus jelentésük sincs. Az Alföld--Dunántúl, a főváros-vidék térkategória-pároknak inkább van szimbolikus tartalmuk, és számos település neve hordoz valamilyen többletjelentést, nem csak az ott lakók számára.

2) A marxista és a neoliberális teoretikusok Magyarországon is az új térszint kialakulását a gazdasági reálfolyamatokból látják kinöni, különösen gyakori, hogy a gazdaság korszerü (klaszterszerủ) müködtetésének színterét látják benne. De Magyarországon a szocialista nagyvállalatok megszủnésével a hagyományos termelési kapcsolatok felbomlottak, és helyettük még nem alakultak ki új regionális gazdasági együttmüködések (hálózatok, klaszterek). A létező kapcsolatok (al)ágazatonként és gyakran vállalatonként is különbözö területegységeket fednek le, és nem eredményeznek hasonló határokkal rendelkező gazdasági régiókat. Kivételt néhány funkcionális körzet jelent, mint például a balatoni üdülökörzet. A magyar regionalizáció nem támasztható ala a gazdaság reálfolyamataival. 
A magyar regionalizációt egyértelmüen nem alapozhatjuk a regionális fejlettségbeli különbségekre és az azokból adódó teendőkre sem. A konkrét nagyrégiókon belüli fejlettségbeli különbségek nagyobbak, mint a régiók közöttiek. A fejlett régiókban is vannak belső perifériák és az elmaradottakon belül is dinamikusabb központok. Vannak olyan területek, amelyek az országos vagy uniós átlaghoz viszonyítva elmaradottnak minősíthetők, de önmagukhoz képest dinamikusan fejlödnek, és vannak, amelyek depresszióba süllyedve kerültek ugyanarra a szintre. Ezért számos területfejlesztési szakember azt állítja, hogy ma Magyarországon a regionális politika legmegfelelőbb beavatkozási szintje a kistérség (mikrorégió).

A már kialakított tervezési-fejlesztési régiók (NUTS 2) gazdasági érdekei jelenleg csak egy szempontból értelmezhetók, minél több küllsö forrás megszerzése a régiók közötti versenyben. De már a megszerzett források megyék, kistérségek és települések közötti felosztása is felbontja az ez irányú érdekközösséget, és belső versenyt, vagy még inkább politikai lobbizást hív életre. A regionális versenyképesség erösítésének, a kooperációban rejlő lehetőségének, a regionális erőforrăsok minél hatékonyabb felhasználásának és „exportálásának” artikulálása és megvalósítása sokkal nehezebb feladat. Jelenleg a munkavállalót saját munkaerejének településen vagy kistérségen belüli minél jobb hasznosítása, a vállalkozót elsősorban a belső gazdaságosság javítása, a települések és egyéb intézmények vezetỏit a sürgető finanszírozási gondjaiknak a megoldása köti le, és legfeljebb ezekhez való hozzájárulása arányában érdekli öket a regionális szintủ politika. Bár kétségtelen, hogyha létrehozzuk a régiókat, akkor az új politikai térelem kedvezőbb lehetőségeket biztosít a régión belüli együttmúködésre, a közös külső fellépésre.

3) Magyarországon jelenleg pragmatikus politikai regionalizáció folyik, amelynek fö ágense nem az autonóm regionális politika megerösítése, a decentralizảció erösítése, de még csak nem is a kormányzás hatékonyságának növelése, hanem uniós csatlakozásunkból következỏen az Európai Unió regionális és kohéziós politikája és a mellé rendelt eszközök felosztásának és felhasználásának a logikája. Ebben az europaizációs konstellációban nem a magyar állam és pláne nem a magyar társadalom határozta meg a különbözỏ területegységek, így az új régiók helyét és szerepét a magyar társadalmi gazdasági rendben, hanem az európai technokrácia, amely a bürokráciát jellemző technikai racionalitása alapján hozza meg döntéseit. A demokráciadeficit mellett kialakított konceptuális keretek, múködési rendszerek külső késztetésre adaptálódtak a magyar viszonyokra. Néhány regionális kezdeményezéstől eltekintve a regionalizáció alapvetően kívülröl és felülröl vezérelt folyamat. A helyi összefogáson alapuló kezdeményezések sem a valós érdekek felismerésén vagy tudatos értékválasztásokon nyugodtak, csak a versenyelöny szerzése érdekében elébe kívántak menni a folyamatnak. Tehát a területi közigazgatási rendszer, a belső hatalmi struktúra újbóli megváltoztatása - a két világháborút követó változásokhoz hasonlóan - egy kívülröl kezdeményezett folyamat, amelynek mozgatórugói az új gazdaságpolitikai és biztonságpolitikai érdekek. Természetesen nem békeszerzödések jelentik az új térfelosztás alapjait, hanem egyéb nemzetközi szerződések, és az ideológia is más. A gazdasági internacionalizmus (globalizáció) a 
tőke és a munkaerő szabad mozgását támogatja, és a közös célok érdekében történő közös cselevést a megszerezhetö támogatásokkal ösztönzik. De úgy tünik, hogy a regionalizmushoz füződỏ remények nem igazolódtak, így kétségek merültek fel a regionalizáció továbbvitelét illetỏen, a kibővített Európai Unió belsỏ struktúráját alapvetỏen a nemzetállamok és az azokból alkotott érdekcsoportok adják, és a nemzetállamokon belüli térfelosztás inkább újra belső nemzeti üggyé válik.

A magyar politikai elit, a mindenkori kormányzat fogadókész a nemzeti kormányok funkcióinak megerősítésére, a regionalizáció államosítására. Partner abban, hogy az útjára bocsátott regionalizáció úgy folytatódjon, hogy ne sérüljenek tovább a központi irányítás érdekei, az új regionális intézmények is a vertikális hierarchiába integrálódjanak.

Valójában nem passzív médiumokra lenne szükség, ahol a nemzeti és a helyi szereplök találkoznak, hanem önálló politikai aktorokra. Az új régiók nem csupán tárgyai, hanem aktív alanyai csak úgy lehetnének a társadalmi gazdasági folyamatoknak, ha saját határaikon belül autonóm döntési kompetenciával rendelkeznének. E döntéseket nem determinálhatnák kívülröl, söt ad absurdum, külsö logika alapján meg sem határozhatók! Decentralizált struktúrában, valós funkciómegosztás esetén a régiószintü döntések nem is helyettesíthetök más szintủ döntésekkel. A regionális szintü intézmények függetlenségét a munkamegosztásban elfoglalt helyük, saját funkcióik, hatásköreik biztosíthatják, ami kiegészíti a központi és helyi cselekvéseket. Tehát nem elég, ha például a kormány regionális terveket készít - ez legfeljebb a kormány régiópolitikáját tartalmazhatja -, hanem az szükséges, hogy a regionális és a lokális szereplők saját maguk készítsék e terveket és hozzák meg a tervdöntéseket, és rendelkezzenek azok végrehajtásához szükséges eszközökkel. Magyarországon a regionális funkciókat a központi szint kívánja ellátni a regionális szereplökkel való szorosabb együttmüködés segítségével. A jelenlegi hatalmi-tervezési rendszerben a regionális (és helyi) szint nem integrálódik az EU politikai (döntési) terébe, a regionális és helyi intézmények még csak alkupozícióba sem kerülnek. (Igaz, az „ír sikertörténetnek" sem voltak aktiv részesei a helyi és regionális politika szereplöi. A helyi politikusok a hivatalos [normatív] kapcsolatokon kívüli utakat járták, és közvetlenül vették fel a kapcsolatokat külföldi partnereikkel, nem regionális, hanem probléma- és fejlesztésorientált lobbicsoportokat alkottak.)

A magyar regionalizáció jövője kapcsán ma a kulcskérdés az, hogy a Tizenkettek csatlakozásával jelentős fordulatot vesz-e az EU regionális politikája, és ha csökken a regionalizáció külső késztetése, akkor megfogant-e olyan vitalitással a regionalizáció a magyar politikai diskurzusban, hogy önkormányzati régió létrehozásához vezessen.

Az új regionalizáció európai hajtóerői kifulladni látszanak, és Magyarországon sem látom, hogy a politikai retorika mögött valós elkötelezettség lenne a decentralizált közigazgatási struktúra megvalósítása mellett. Sokkal valószínübbnek tartom, hogyha fordulat áll be az Európai Unió kohéziós (regionális) politikájában, akkor Magyarországon sem erösödik tovább a regionalizmus, hanem a mindenkori problémákhoz leginkább igazodó terúleti szinten és a legjobbnak tartott eszközökkel próbáljuk meg kezelni a terulleti sajátosságokat mutató gondjainkat. Megjegyzem, a 
magyar megyei önkormányzatok tényleges cselekvöképessége rávilágít arra, hogy akár a választott regionális önkormányzatok sem garantálják a decentralizált mủködést. Egyrészt a megyei önkormányzatoknak alig vannak jogosítványaik, másrészt a politikusaink nem tekintik a megyéket az elkülönült érdekek érvényesítési színterének, hanem sokkal inkább a pártpolitikák végvárainak. Úgy gondolom, az ilyen típusú regionális önkormányzatok nem járulnak hozzá a demokrácia kiteljesítéséhez.

Mint láttuk, a regionalizmus nem új Magyarországon, és valószínủ, hogy az „új regionalizmus" szándékával ellentétben nem a posztfordista nyitott gazdasági teret eredményezi, hanem tradicionális értékekböl és hagyományos módszerekkel építkezik. Így a régiók megerősítése gyakran a regionális határok és az oppozíció lehetőségének a megerősitését is jelenti, ami uitközhet az új regionalizmus ideológiájával, amely a határok és a (hátrányos) különbségek megszüntetését, a szabad versenyt célozta meg. Az új regionalizmus, mint a gazdasági globalizációs erők által a nemzeti kormányok és az erősödő lokalizmus ellen alkalmazott stratégia fordítva is elsülhet! Így nem meglepö, hogy a területi identitás és kötődés erősítése, a területi érdekek privilegizálása negatív protekcionalizmusnak, provincionalizmusnak minősül, így várható, hogy az új regionalizmust kezdeményezö erők megvonják a további támogatásukat.

Az Európai Unióban a decentralizációhoz kötődö koncepcionális vita a szubszidiaritás, a föderalizmus és a regionalizmus fogalmai és egymáshoz való viszonyuk körül forog. Ezen elvek, fogalmak egyértelmủen nincsenek rögzítve. Schuman és Dolors víziójában az idealizált európai térstruktúra három önkormányzati szintet jelent, az önkormányzatit, a regionálist és a nemzeti szintet. Az Európai Közösség, majd Európai Unió sohasem lett a „régiók Európája”, megmaradt a nemzetállamok szövetségének, és a döntéshozatal még ma is a kormányközi egyeztetések eredménye. A különböző szintü önkormányzatokat képviselö Régiók Bizottságának mind a mai napig csak konzultatív tanácsadói szerepe van. A közösségi jog nem legitimálja a régiót, még ma is elsősorban, mint a lehetséges strukturális támogatások címzettje jelenik meg. Csak egyirányú - a nemzeti kormányok által közvetített - kapcsolat van a szupranacionális intézmények és a régiók között. A regionalizmus-mozgalom a kilencvenes évek közepén érte el csúcspontját, de azt követöen más fontosabb kérdések kerültek a közös európai politika fókuszába, és az új regionalizmus háttérbe szorulhat. Az EU 27 tagállamra való bővülésével még tovább csökken annak az esélye, hogy a regionális szint nagyobb szerepet kapjon az EU mủködésében. A nem fizikai fallal kettéosztott EU-ban országcsoportok és nemzeti érdekek érvényesítéséröl folyik a vita és egyre kevesebb szó esik a „régiók Európájáról”. A feladat, hogy az „USA Európájából” és a „Szovjetunió Európájából” létrehozzuk az „európaiak Európáját”, háttérbe szoríthatja a szupranacionális diskurzusban a nemzetállamokon belüli régiók kérdéskörét. Európa számára a fő kérdés ma nem a ,régiók Európája”, hanem az európai régió helye a világban, a triád harca!

A kohéziós politika reformjáról 2004 márciusáig napvilágot látott információk alapján a régiók jövőbeni szerepének tekintetében sok a bizonytalanság, hiănyoznak az EU explicit állásfoglalásai. A retorikában még erős a területi szolidaritás, de már 
kevesebbet lehet hallani, olvasni a regionalizmus érdekében történő konkrét lépésekről. Brüsszel elsődleges partnerei ma is a nemzetállamok kormányai, és a Tizenkettek csatlakozásával csökken a realitása annak, hogy a régiók szerény szerepköre, a Régiók Bizottságának a hatásköre erősödjék. A kohéziós politika területi vetületét, súlypontját egyre inkább a tagországok jelentik. ${ }^{12} \mathrm{~A}$ kohéziós politika konvergenciaprioritásának megvalósítására szánják a Kohéziós Alap, az Európai Regionális Fejlesztési Alap és az Európai Szociális Alap pénzeszközeinek 78\%-át. A regionális versenyképesség és foglalkoztatás javítására szánt $18 \%$-os keret jelentős része is nemzeti szintủ foglalkoztatási programok keretében lesz felhasználva. A NUTS 2-es szintủ régiók kiemelt kezelése halványodik, és újra nagyobb szerephez jutnak a városok és a falvak, a városias és a rurális (kis)térségek.

A 2004-2006-ra készített magyar Nemzeti Fejlesztési Terv (NFT) kapcsán a brüsszeli szakértők hangsúlyozták, hogy a decentralizációt folytatni kell, de a gyakorlatban inkább az átláthatóságra, az ellenőrizhetőségre tették a hangsúlyt, mint esetleg ezek rovására a regionalizáció erősítésére. A tervezés elörehaladtával egyre fogyott a regionális szempontok, érdekek megjelenítése és érvényesítése. Brüsszel nem minden ok nélkül - a regionális szint kiépítésének hiányossågaira hivatkozott, míg itthon újra beigazolódott, hogy a központi hatalom önként nem ad le jogosítványokat. Az elkészültt NFT és az ez alapján készült Közösségi Támogatási Keretterv csak horizontális programokat foglal magában. Nevével ellentétben a maradékelv alapján „betyárbecsületből” készült regionális operatív program (ROP) is annak minősíthető. Az NFT és a ROP készítése során érezhető volt, hogy az Európai Unió nem helyez hangsúlyt a régiók megerősítésére, csak a végrehajtásban szán szerepet nekik, és hogy a magyar kormánynak sincs olyan regionális jövőképe, amely mellett elkötelezettséget vállalna, és a köré szervezné a különböző cselekedeteit. Az NFT és különösen a ROP nem alkalmas a hátrányos regionális különbségek mérséklésére, végrehajtásuk növelni fogja a már meglévő területi különbségeket.

Most kezdődik az új generációs nemzeti fejlesztési terv készítése. A munka megkezdésekor kardinális kérdés lenne a régiók szerepének tisztázása, a regionális intézményrendszer megerösítése, de brüsszeli tisztségviselök újra nem állnak ki a régiók nagyobb szerepvállalása mellett. A megkérdezettek hezitálnak, nem ritkán egymásnak ellentmondó válaszokat adnak. A tervezés megkezdésének körülményeiből, az illetékes vezetők nyilatkozataiból arra lehet következtetni, hogy most sem lesznek önálló regionális szintü programok, sőt most formálisan sem lesz még csak egy gesztusértékủ regionális operatív program sem. A jelenlegi regionális intézményrendszer „bedolgozói” szerepkört kap az új központi tervek készítésében és a majdani végrehajtásban. A regionális fejlesztési ügynökségek egyre inkább a kormányzati szervezetek dekoncentrált intézményeiként müködnek, és a regionális fejlesztési tanácsok önálló döntéshozatala szük decentralizált források elosztására korlátozódik. A brüsszeli és kormányzati hezitálás a regionalizmus eltökélt képviselöinek a hitét is megrengetheti. 


\section{Végkövetkeztetés}

Az 1990-es rendszerváltás és az Európai Unióhoz való csatlakozásunk nem járt a területfejlesztés értelmezése és a regionalizáció mozgatórugóit tekintve paradigmaváltással. A „szocialista” rajonírozási és a magyar körzetesítési, majd regionalizációs elméletek és gyakorlati próbálkozások nem álltak messze az „európai új regionalizmus” alapgondolatától. Az „új Európa új térszerkezetet igényel” gondolat is marxista gyökerü, hiszen a kapitalista termelési mód változásából vezeti le az új térszerkezet, az új területi léptékek szükségességét. Mindkét megközelítés a modern termelési tényezök területi kereteit látta a régióban, amely egyrészt adott a környezö világunkban, így megismerhetö és leírható, másrészt úgy gondolták, hogy ahol nincs, ott regionális intézményrendszert kell kialakítani és beintegrálni az irányítási rendszerbe. A szocialista teória mindig hangsúlyozta a gazdasági törvényszerüségek és a tér objektivitását, azokat ható-okként (causa efficiens) tüntette fel. Az európai új regionalizmus cél-okok (causa finales) elérésének eszközét látja a régiókban, de a tervezés és a megvalósítás során törekszik a számszerüsítésre, az eredmények materiális számbavehetöségére.

Ha az EU-t elsősorban a nemzeti kormányok (európai multinacionális cégek) közös gazdasági „vállalkozásának” tekintjük, akkor a belsö térstruktúra alakításánál is a gazdasági-versenyképességi szempontok az elsődlegesek, amelyek nemzeti és regionális határok nélküli egységes piac megteremtését kívánják meg. Ebben a globalizálódó szupranacionális gazdasági hipertérben nehéz megtalálni a gazdasági indíttatású regionalizáció, a tér-fregmentálás hajtóeröit. Az alulról építkező politikai-kulturális regionalizáció éppen e trendek elleni védelmet szolgálhatja, ami ellentmond az új regionalizmus eszményének.

Mivel a regionalizáció nem egy objektív folyamat, a magyar régiók nem a reálfolyamatok leképezései, hanem politikai (társadalmi) diskurzusban alakuló politikai intézmények, így szabad akarat függvénye, hogy milyen típusú és hatáskörủ régiókat alakítunk ki Magyarországon. A globalizációs erők jelenleg még nem gondolkodnak a hagyományos kisléptékü térkategóriákban, és a regionalizáció továbbvitelének EU-s mozgatóeröi is gyengülni látszanak, így elsősorban a hazai diskurzus (hatalmi harc) eredményétól függ, hogy a jelenleg is meglévő fejlesztési-tervezésistatisztikai régiókat integrálni kívánjuk-e a közigazgatási rendszerünkbe. A térszerkezet átalakítására irányuló reformok megkerülhetetlen külsö kényszer nélkül az elmúlt száz évben elbuktak. Úgy látom, hogy külső támogatottság (kényszer) hiányában a magyar regionalizációs erök ma sem elegendőek az önkormányzati régiók kialakításához, egy decentralizáltabb államigazgatás kiépítéséhez. A regionális önkormányzatok létrehozása csak egy átfogó közigazgatási és államháztartási reform keretében történhetne meg. E racionalizáció a központi és az ágazati hatalom gyengítésével, a megyék megszüntetésével és a kistérségi szint megerösítésével is kellene hogy járjon. Ennek ma nem látom realitását, amikor az Európai Unión belül a feladat a hátrányos megkülönböztetésünk felszámolása, a nemzeti érdekek érvényesítése, ami egységes nemzeti akaratot és fellépést igényel. A magyar 
regionalisták számára nem kis feladatot jelent az elkövetkezỏ években, hogy megóvják a regionalizáció eddigi eredményeit, és elérjék, hogy a mai regionális intézmények valós szereplöi legyenek a területfejlesztésnek. Ennek érdekében csökkenteni kell a regionális fejlesztési tanácsokban a kormányzati szerepvállalást, növelni kell a saját hatáskörben szabadon elkölthető forrásokat, és regionális funkciókat kellene ellátni a mai újraelosztó-közvetítői szerepkör helyett. Ha pedig megmaradnak a megyék, akkor a területi önkormányzatok híveinek is van mit tenni, az érdemi megyei önkormányzati mủködés megvalósítása érdekében.

\section{Jegyzetek}

I A történelmi determinizmusból Marxnál sem következik az, hogy a természeti és művi környezet egyértelmüen meghatározná az emberi cselekvések térstruktúráját. A társadalmasított szubjektumok egyre nagyobb mértékben maguk hozzák létre életterüket a kơrnyezö világból. E tudatos tevékenységet ideálképek, célok vezérlik.

${ }^{2}$ Pl. Sartre és Althusser Franciaországban, Adomo, Benjamin, Marcuse Németorzágban, Della Volpe és Colletti Olaszországban.

${ }^{3}$ Az 1945-ös és 1990-es rendszerváltás is átrajzolta a gazdasági teret, ătértékelte a telepuiléseket, a régiókat.

${ }^{4}$ Posztmodern iróniával mondhatnám, hogy ma mindenki megírhatja Weber, Marx stb. "utánzatát", múvészettörténeti értelemben historizáló változatát, ami összességében nem valami eredendően újhoz vezet, de mindenképpen plurálisabb, eklektikusabb nézetrendszerhez. Jameson (1991) a termelési mód változásának helyébe a késő kapitalizmus kulturális logikáját állította, mint új téralkotó folyamatot. Annak ellenére, hogy Soja leírja (Soja 1989, 189), hogy a regionális megközelítés lehet alkalmas a helyi ếs a globális szint közötti közvetílésre, szintetizálásra, véleményem szerint könyvének egésze mégis azt sugallja, hogy nagyobb jelentőséget tulajdonít a nagyvárosoknak, és a régiókat is elsősorban mint nagyvárosi agglomerációkat, térségeket értelmezi.

${ }^{6}$ E folyamatban 1983 óta kiemelkedỏ szerepet játszott az MTA Regionális Kutatások Központja. Az ott dolgozókhoz kapcsolódik az oktatásban, a tudományban, a szakirodalomban e problémakör önálló megjelenítése és elfogadtatása.

${ }^{7}$ Természetesen vannak esetek, amikor valamilyen cél érdekében szigorú területi határokra van szükség (pl. EU külső határai), de egy gazdaságfejlesztést segítö intézmény esetében ezek kevésbé fontosak.

${ }^{8}$ Hajdú (2001) Magyarország közigazgatási földrajza címủ könyvében részletesen bemulatja a magyar államterület térszerkezeti felosztásának tơrténeti alakulását.

9 PI. Benisch Artúr, Hantos Gyula, Magyary Zoltán, Prinz Gyula elképzelései.

${ }^{10}$ Hajdú $(2001,156)$ szerint „Ennek egyértel mủen az az oka, hogy a kormányzat fenn kívánta tartani az államterület revíziojának az igényét, mégpedig jelentős részben történeti jogokra hivatkozva, így az országon belüł nem változtatı meg radikálisan a történeti megyerendszent." Tehát a változtatásoknak külsö politikai okai voltak, majd az elmaradó reformok belsỏ politikai okokra vezethetök vissza.

"Ide sorolom a regionalizáció alátámasztását szolgáló kísérletek közül azokat, amelyek a gazdasági folyamatokban, klaszterekben vélik felfedezni a régiók kialakításának indokait, és ennek megfelelöen a gazdaságfejlesztéshez kötik azok funkcióit.

${ }^{12}$ Ez eredhet az eddigi kohéziós politika tanulságaiból is, mivel a regionális különbségek mérséklésében szerényebb eredményeket lehet elkönyvelni, mint az országok közötti különbségek mérséklésében. De jelentheti annak belátását is, hogy a régiók nem váltották be az új neoliberális pol itika végrehajtásában hozzájuk füzőtt reményeket. Az irányítás bürokratikus szempontjai is az egyszerüsítés mellett szólnak. 


\section{Irodalom}

Castells, M. (1999) Grassrooting the space of flows. - Urban Geography. 4. 294-302. o.

Dear, J.M. (2000) The Postmodern Urban Condition. Blackwell Publishers, Oxford.

Faragó L. (1991) Posztmodern: a modernizáció kritikája avagy új kihívás. - Tér és Társadalom. 4. 1-16. o.

Faragó L. (2003) A tér kép egy olvasata és a „területi” tervezés. - Tér és Társadalom. 1. 19-40. o.

Foucault, M. (1991) A diskurzus rendje. - Holmi. 3. 7. 686-889. o.

Fürst J. (1954) A regionális tervezés általános kérdései. Felsőoktatási Jegyzetellátó Vállalat, Budapest.

Goodman, R. (1979) The Last Entrepreneurs. America's Regional Wars for Jobs and Dollars. Pantheon, New York.

Hajdú Z. (2001) Magyarország közigazgatási földrajza. Dialóg Campus Kiadó, Budapest-Pécs.

Harvey, D. (1990) The Condition of Postmodernity. An Enquiry into the Origin of Cultural Change. Blackwell, Oxford.

Illés I. (2001) Régiók és regionalizáció. - Tér és Társadalom. 1. 1-23. o.

Jameson, F. (1991) Postmodernism, or the Cultural Logic of Late Capitalism. Duke University Press, Durham.

Kant, I. (1981) A tiszta ész kritikája. Akadémia Kiadó, Budapest.

Keating, M. (1998) The New Regionalizm in Western Europe. Territorial Restructuring and Political Change. Edward Elgar, Cheltemham, UK.

Koloszovszkij, N.N. (1969) Teorija ékonomicseszkogo rajonirovanija. Goszpolitizdat, Moszkva.

Krajkó Gy. (1987) A Szovjetunió gazdaságfóldrajza. Tankönyvkiadó, Budapest.

Lefebvre, H. (1991) The Production of Space. Blackwell, Oxford.

Massey, D.-Jess, P. (eds.) (1995) A Place in the World. Oxford University Press, Oxford.

Paasi, A. (2001) Europe as a social progress and discourse. Considerations of place, boundaries and identity. - European Urban and Regional Studies. 1. 7-28. o.

Searle, J.R. (2000) Elme, nyelv és társadalom. Vince Kiadó, Budapest.

Soja, E.W. (1989) Postmodern Geographies. The Reassertion of Space in Critical Social Theory. Verso, London.

Szjomuskin, A.T. (1977) Problemü territorial'nogo upravlenija ékonomikoj. Ékonomika, Moszkva.

Varró K. (2004) A tér, mint diszkurzív termék. - Tér és Társadalom. 1. 73-91. o.

\section{THE DRIVING FORCES OF REGIONALISM IN HUNGARY LÁSZLÓ FARAGÓ}

Nowadays a quite actual question is how to carry on the Hungarian regionalization. This study aims to assist in the establishment of the decision by discussing the ideological and spatial theory basis of regionalization, and by the evaluation of the European new regionalization and the Hungarian practice. It proves that the base of the actual dominant view is materialist, Marxist and neoliberalist. In this aspect the transition of 1990 did not bring about paradigm changes in this field. Facing this opinion we recognize the decisional nature of developing regions but current processes lack the imperative material or real factual fundaments.

Thus it is necessary to develop an alternative ideological founding and the use of a practical approach. When discussing the Hungarian relations the study shows the nationalistic cultural bases of the Hungarian regionalization do not exist since Trianon treaty. There is no reason even by the spatial dimension of the actual economic processes to establish regions below national level. In Hungary regionalization occurs mainly in scientific and political discussions. The driving-force is not the establishment of more efficient and democtratic state-strucutre, and the autonomous regional political environment, but in the highest degree the external European Union pragmatist factors. According to the author the "European new regionalism" has started to blown, and it is doubtful that without European Union support the inner impulsive forces will be able to carry on the regionalism, which will be decided by the power fight of non equal bodies. 